\title{
Quality characteristics of beef in thermoelectric cooling system combined with plasma during storage
}

\author{
Ki-Hyun Kwon*, Jung-Min Sung, Ji-Young Kim, Byeong-Sam Kim, So-Hee Kim \\ Korea Food Research Institute, Seongnam 13539, Korea
}

\section{열전소자 장치 및 플라즈마 처리에 의한 소고기 저장 중 품질특성}

\author{
권기현*·성정민 · 김지영·김병삼·김소희 \\ 한국식품연구원
}

\begin{abstract}
This study was performed in order to examine the effect of a thermoelectric cooling system combined with plasma on beef. Beef was studied in a box with a thermoelectric cooling system and plasma generation apparatus (TCS-1), a box with thermoelectric cooling system (TCS-2) and a polystyrene box (control). A temperature inside the thermoelectric cooling system was kept below $2^{\circ} \mathrm{C}$, and volatile basic nitrogen (VBN) values of TCS-1 and TCS-2 were $7.72 \mathrm{mg} \%$ and $9.20 \mathrm{mg} \%$, respectively. The thiobarbituric acid (TBA) value $(0.52 \mathrm{mgMA} / \mathrm{kg})$ of TCS-1 was significantly lower than that $(0.91 \mathrm{mgMA} / \mathrm{kg})$ of TCS-2. For volatile basic nitrogen (VBN) value, TCS-1 maintained freshness compared to TCS-2, since the freshness of TCS-1 value (6.98-9.77 mg\%) was less than that of TCS-2 (6.98-11.45 mg\%) during storage. The microbial counts of TCS-1 and TCS-2 were 4.62 log CFU/g and $7.09 \mathrm{log}$ CFU/g, respectively, on the $7^{\text {th }}$ day, which were lower than that $(8.45 \log \mathrm{CFU} / \mathrm{g})$ of control on the $3^{\text {rd }}$ day. Sensory evaluation of TCS-1 showed the highest scores for appearance, color, juiciness, and overall acceptability than the others. In conclusion, TCS-1 was effective for maintaining freshness of beef during storage.
\end{abstract}

Key words : thermoelectric cooling system, phase change material, beef, storage, sensory evaluation

\section{서 론}

국민소득의 증대와 함께 소비자의 고품질 농축산물에 대한 수요와 관심이 날로 증가하고 있다. 이에 따라 안전하 며 고품질의 농축산물을 소비자에게 공급하기 위해서는 기초산물의 수확, 가공, 저장뿐만 아니라 안전한 농축산물 의 신선도 유지를 위한 유통체계의 개선, 품질 및 안전성 평가기술 개발을 위한 노력이 보다 더 요구되고 있다(1) 최근 국내 신선편이식품의 시장 규모는 성장하고 있으나 신선식품 유통환경과 인프라의 미비로 품질유지를 위한 효과적인 유통관리가 필요한 실정이다. 유통관리를 위한 살균방법에는 화학적 살균방법과 온도의 상승을 최소로

*Corresponding author. E-mail : kkh@kfri.re.kr Phone : 82-31-780-9258, Fax : 82-31-780-9144

Received 2 December 2016; Revised 16 January 2017; Accepted 19 January 2017.

Copyright (c) The Korean Society of Food Preservation. All rights reserved.
하며 살균효과가 있는 물리적 살균방법이 있다. 화학적 살 균방법은 화학물질의 첨가에 의해 새로운 위해요소가 발생 하는 등의 우려가 있으며, 물리적 살균공정으로는 방사선 조사, 전자빔, 오존, 광펄스 등을 이용하는 다양한 기술이 있다. 물리적 살균방법으로 사용되고 있는 기술 중 하나가 플라즈마 식품 처리기술이다. 플라즈마는 높은 반응성을 가진 라디칼 $\left(-\mathrm{OH},-\mathrm{H},-\mathrm{HO}_{2}, \mathrm{H}_{2} \mathrm{O}_{2}\right)$ 및 오존 등을 생성하여 살균력을 가지며 공정 중 열이 발생하지 않아 식품특성상 열처리가 불가한 식품뿐만 아니라 가공식품 제조시설이나 식품 용기의 위생화에도 유효할 것으로 생각된다. 플라즈 마를 이용한 식품 미생물 저감화 기술은 온도가 높지 않게 형성된 플라즈마를 이용하여 식품에 오염된 미생물을 저해 시키는 기술이다. 비열 플라즈마 기술은 환경, 의료 등 식품 외의 분야에서 살균 및 소독 기술로 많이 연구되었지만, 식품 내에 존재하는 미생물 저감화를 위한 기술로서의 연구 는 아직 미흡한 상황이다(2-6).

소고기는 일반식품과 달리 영양가가 높은 고단백 식품인 반면에 세균오염이 비교적 용이하고 쉽게 변질되는 특성이 
있으며 동물에서 사람으로 전파되는 인수공통전염병, 기생 충 질환 및 인체 병원성 미생물 등 전파 가능성이 높은 편이다. 따라서 사육단계에서부터 도축, 가공, 유통 및 소비 에 이르기까지 철저하고 일관성 있는 위생관리가 절대적으 로 필요하다. 또한 소고기는 우수한 등급일지라도 유통 중 온도관리가 부실하면 품질저하가 초래되고 때로는 식중독 의 위험에 노출 될 우려가 있다(6-8). 또한 생육을 냉장 유통 시키기 위해서는 도축장에서부터 소비자에 이르기까지 전 유통망에서의 엄격한 온도관리가 필수적이다. 미생물의 성 장과 대사는 저장온도에 가장 큰 영향을 받으므로 포장육의 저장 수명은 저장온도에 의해 좌우된다고 할 수 있다(9).

본 연구 농산물의 유통 중 안전성을 유지할 수 있는 저온 이동식 컨테이너를 제작하여 연구를 수행하였으며 이동식 컨테이너 내부에 잠열재와 열전소자 장치를 삽입하여 온도 를 유지할 수 있도록 하였다. 또한 플라즈마 장치를 이용하 여 살균효과를 비교하였다. 현재 신선식품의 유통에 이용 되고 있는 스티로폼(EPS, expandable polystyrene) 박스를 대조구로 하였으며, 개발된 저온 이동식 컨테이너와 비교 하여 저장된 소고기의 품질특성을 조사하였다.

\section{재료 및 방법}

\section{실험재료 및 저장 조건}

소고기는 같은 개체의 소에서 등심부위를 서울 소재 하 나로 마트에서 구입하여 실험에 사용하였으며, 두께 $1 \mathrm{~cm}$ 로 각각 개별 포장하여 저장하였다. 저온 이동식 용기(TCS, thermoelectric cooling system)는 잠열재와 열전소자 적용하 여 직접 제작한 것으로(Fig. 1) 플라즈마 처리에 따라 TCS-1 과 TCS-2로 구분하여 내부 온도가 각각 $2^{\circ} \mathrm{C}$ 가 유지되도록 작동시킨 후 실험에 사용하였다. 열전소자는 냉각 및 가열 용 열전소자로 각각 2HT-085-S, HT-15-15-S 모델을 이용하 였으며, 열전소자물질로는 상온에서 높은 열전효과를 얻기 위해 $\mathrm{BiTe}$ 계를 선택하였다. 온도센서가 부착되어 온도 모 니터링이 가능하며 충전이 용이한 리튬폴리머 배터리를

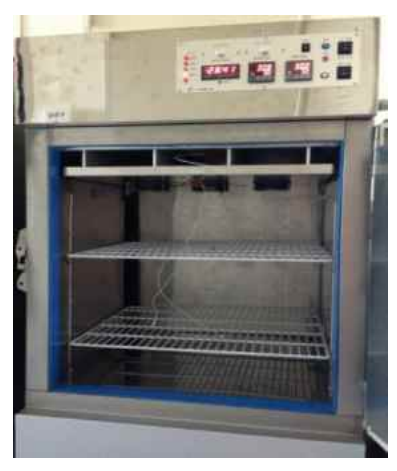

TCS-1

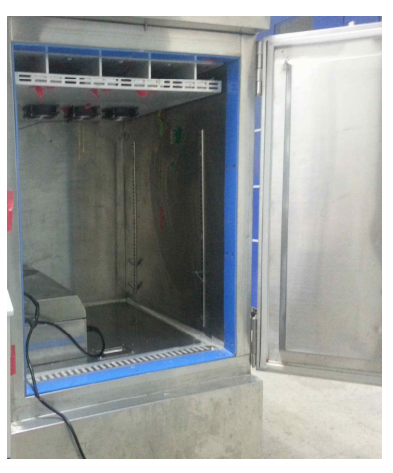

TCS-2
Fig. 1. Transportable thermoelectric cooling system.
장작하여 24시간 연속적으로 사용 가능하도록 제작되었다. TCS-1 수배송 컨테이너에는 플라즈마 장치(Water Link, Pyengtaek, Korea)를 작동시켰다. 플라즈마 장치는 오존농 도로서 $100 \mathrm{mg} / \mathrm{h}$ 출력되는 장치로 60 분 단위로 1 분간 작동 하도록 제작되었다. 대조구에는 일반 시중에서 판매되는 축냉팩을, TCS-1, TCS-2 처리구에는 water $60 \%$ 와 n-tetradecane $\mathrm{C}_{14} \mathrm{H}_{30} 40 \%$ 의 비율로 혼합하여 제조한 잠열재 를 넣고 실험하였고 저장 방법은 총 3 가지로 구별하였다 (Table 1).

Table 1. Storage conditions of beef

\begin{tabular}{ccccc}
\hline Treatment & $\begin{array}{c}\text { Thermoelectric } \\
\text { system }\end{array}$ & Ice-pack type & $\begin{array}{c}\text { Storage } \\
\text { temperature }\left({ }^{\circ} \mathrm{C}\right)\end{array}$ & $\begin{array}{c}\text { Plasma } \\
(\mathrm{mg} / \mathrm{hr})\end{array}$ \\
\hline Control $^{1)}$ & $\times$ & $\begin{array}{c}\text { General } \\
\text { Cold pack }\end{array}$ & $-{ }^{4}$ & $\times^{5}$ \\
$\mathrm{TCS}^{2}-1$ & 0 & $\mathrm{PCM}^{3)}$ & 2 & 100 \\
TCS-2 & 0 & PCM & 2 & $\times$ \\
\hline
\end{tabular}

${ }^{1)}$ Conrol, beef in expandable polystyrene (EPS) box.

${ }^{2)} \mathrm{TCS}$, beef in box with thermoelectric cooling system.

${ }^{3} \mathrm{PCM}$, phase change material.

4), room temperature.

${ }^{5)} \times$, not treated.

\section{온도측정}

온도측정은 Termo Recorder(TR-52, T\&D Co., Nagano, Japan)를 이용하여 온도변화 기록을 측정하였으며, 측정 부위는 잠열재(phase change material, $\mathrm{PCM}$ ), 이동식 컨테이 너 내부(inside), 시료(sample)을 각각 측정하였다.

\section{$\mathrm{pH}$ 및 색도 측정}

소고기의 $\mathrm{pH}$ 측정은 시료 $10 \mathrm{~g}$ 과 증류수 $20 \mathrm{~mL}$ 을 homogenizer(AM-7, Nihonseiki Kaisha Ltd., Tokyo, Japan) 로 균질화하고 $\mathrm{pH}$ meter(AB 15, Fisher Scientific, Waltham, $\mathrm{MA}, \mathrm{USA}$ )를 이용하여 3번 반복하여 측정하였다. 색변화 측정은 Chromameter(Minolta CR-200, Osaka, Japan)를 이용 하여 3 반복하여 측정하였다.

\section{Volatile basic nitrogen(VBN) 측정}

$\mathrm{VBN}$ 측정은 Conway 법을 이용한 미량확산법(10)에 준 해 측정하였다. 시료 $5 \mathrm{~g}$ 에 증류수로 $50 \mathrm{~mL}$ 까지 부피를 맞춰준 후 homogenizer(T25, Janken \& Kunkel, Staufen, Germany)로 균질화 한 다음 여과지(Whatman No. 1)로 여과 한다. 여과액 $1 \mathrm{~mL}$ 을 conway dish 외실 왼쪽에 넣고 내실엔 $1 \mathrm{~mL}$ 의 $0.005 \mathrm{~mol}_{2} \mathrm{H}_{2} \mathrm{SO}_{4}$ 을 넣은 후 외실 오른쪽에 포화용 액 $\mathrm{K}_{2} \mathrm{CO}_{3}$ 용액 $1 \mathrm{~mL}$ 을 넣는다. 여과액과 $\mathrm{K}_{2} \mathrm{CO}_{3}$ 용액을 잘 섞은 다음 $25^{\circ} \mathrm{C}$ 에서 60 분간 반응 시킨다. 반응 후 내실에 Brunswik 시약으로 발색시킨 후 $0.01 \mathrm{~N} \mathrm{NaOH}$ 로 적정하였다. 
Thiovarbituric acid(TBA) 측정

소고기를 마쇄하여 $10 \mathrm{~g}$ 을 취한 후 $0.3 \% \mathrm{BHT}$ (butylate hydoxytoluene, Sigma Chemical Co., St Louis, MO, USA) $0.5 \mathrm{~mL}$ 를 넣고 $20 \% \mathrm{TCA}$ (trichloroacetic acid) 용액 $25 \mathrm{~mL}$ 을 가하여 homogenizer로 균질화 한 다음 증류수로 $50 \mathrm{~mL}$ 가 되도록 정용한다. 정용한 후 여과지(Whatman No. 1)를 이용 하여 여과 후 여과액 $5 \mathrm{~mL}$ 와 $5 \mathrm{mM} \mathrm{TBA(thiobarbituric} \mathrm{acid,}$ Sigma Chemical Co.) 용액 $5 \mathrm{~mL}$ 을 가하여 혼합한 후 15 시간 냉암소에 방치한 다음 $530 \mathrm{~nm}$ 에서 흡광도로 측정하였다.

\section{육즙 손실 측정}

소고기의 육즙 손실(\%) 측정은 조사 전과 조사 후의 무게 를 측정하여 계산하였다.

\section{총균수 측정}

총균수 측정은 소고기 표면을 $\mathrm{swab}(3 \mathrm{M}$ Pipette Swab, $3 \mathrm{M}$, St. Paul, MN, USA)을 이용하여 일정 횟수로 문질러 취한 후 단계적으로 희석하여 총균수 측정 배지(Petri film, $3 \mathrm{M}$ )에 접종하여 $37^{\circ} \mathrm{C}$ 에 배양한 후 $\log \mathrm{CFU} / \mathrm{g}$ 으로 나타내 었다.
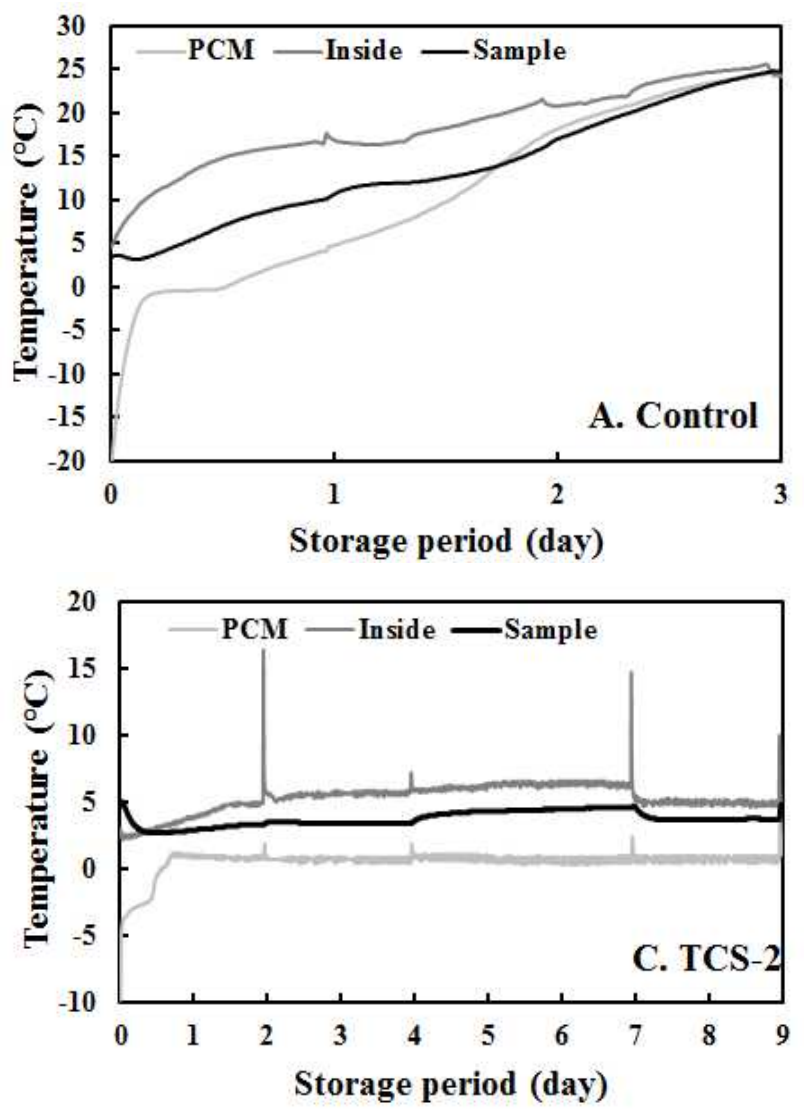

\section{관능평가}

관능평가는 패널 15 명을 선정하여 소고기의 외관 (appearance), 육색(color), 이취(off-flavor), 다즙성(juiciness), 전반적인 기호도(overall acceptability) 항목으로 9점 척도법 으로 평가하였다. 각 항목별 9점은 가장 우수함을 나타내고 1점은 가장 열악한 품질 상태를 나타내었다.

\section{통계분석}

통계분석은 statistical analysis system(SAS) 6.0(SAS Inc., Cary, NC, USA)을 이용하여 ANOVA analysis와 Duncan's multiple range test 방법으로 시료간의 유의성 $(\mathrm{p}<0.05)$ 을 분 석하였다.

\section{결과 및 고찰}

\section{온도측정}

이동식 컨테이너의 잠열재, 내부 및 시료의 온도는 Fig. 2 와 같다. 이동식 컨테이너의 저장 1 일째 대조구인 $\mathrm{EPS}$ box의 잠열재 온도는 $4.8^{\circ} \mathrm{C}$, 저온 이동식 컨테이너 내부는 $16.9^{\circ} \mathrm{C}$, 시료중심은 $10.7^{\circ} \mathrm{C}$ 로 저장 기간이 경과될수록 점차

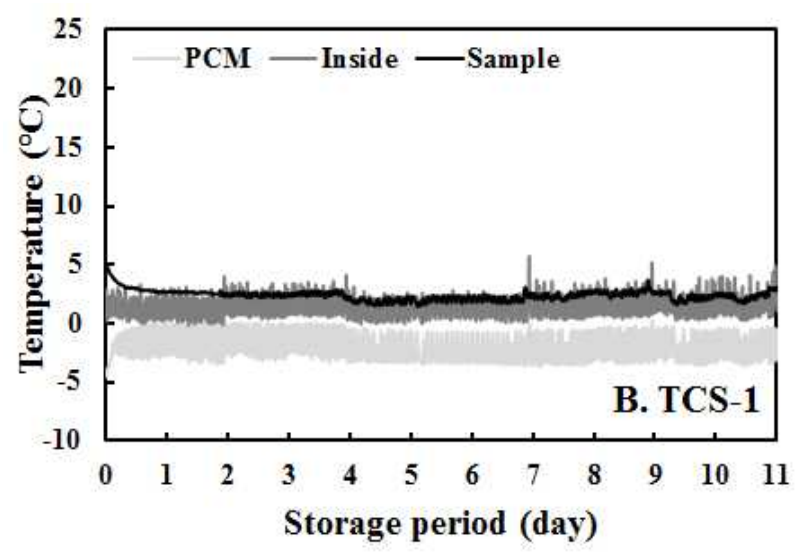

Fig. 2. Changes in temperature of beef during storage.

PCM, temperature of Phase Change Material; Inside, temperature of the inside of the TCS box; Sample, temperature of the sample core. 
상승하는 것으로 측정되었다. 저장 2일째 잠열재, 내부 및 시료 온도는 각각 $18.2,20.8,17.1^{\circ} \mathrm{C}$ 로 측정되었으며, 저장 3 일째에는 잠열재, 내부, 시료온도가 $24^{\circ} \mathrm{C}$ 이상으로 급격히 상승하는 것으로 측정되었다. 저장기간 동안 EPS box의 평균온도는 잠열재 $11.9^{\circ} \mathrm{C}$, 내부 $19.0^{\circ} \mathrm{C}$, 시료 $14.7^{\circ} \mathrm{C}$ 로 측정 되었다. 한편 TCS-1과 TCS-2는 저장 2 일째 잠열재는 -1.3 , $0.7^{\circ} \mathrm{C}$, 내부온도는 $0.8,0.7^{\circ} \mathrm{C}$, 시료온도는 $2.5,3.5^{\circ} \mathrm{C}$ 로 측정 되었고 저장 9 일째에는 잠열재는 $-2.0,1.1^{\circ} \mathrm{C}$, 내부온도는 $2.4,4.0^{\circ} \mathrm{C}$, 시료온도는 $2.5,4.8^{\circ} \mathrm{C}$ 로 TCS-1이 TCS-2에 비해 온도가 유지되는 것으로 측정되었다. 저장기간 동안 TCS-1 의 평균온도는 잠열재 $-1.9^{\circ} \mathrm{C}$, 내부 $1.5^{\circ} \mathrm{C}$, 시료 $2.4^{\circ} \mathrm{C}$ 로 측정 되었고, TCS-2는 잠열재 $0.6^{\circ} \mathrm{C}$, 내부 $5.1^{\circ} \mathrm{C}$, 시료 $3.7^{\circ} \mathrm{C}$ 로 측정되어 저온 이동식 컨테이너 $\mathrm{TCS}-1$ 이 설정온도 $2^{\circ} \mathrm{C}$ 로 온도유지에 적합한 것으로 측정되었다.

\section{$\mathrm{pH}$ 및 색변화}

이동식 컨테이너의 처리방법에 따라 소고기 저장 중 $\mathrm{pH}$ 변화는 Table 2 와 같다. 저장 초기 소고기의 $\mathrm{pH}$ 는 5.25 로 측정되었고, 저장 2 일에 대조구는 5.51, TCS-1은 5.40, TCS-2는 5.41로 측정되었다. 대조구는 저장 3일에 5.71로
증가하였고, 시료의 부패에 따른 분석이 불가능하였다. 저 장 7 일에 소고기의 $\mathrm{pH}$ 는 TCS- 1 은 5.51, TCS-2는 5.70로 저장 초기보다 유의적으로 증가한 것으로 나타났다 $(\mathrm{p}<0.05)$. 소고기의 저장 중 $\mathrm{pH}$ 의 상승은 일반적으로 숙성 중에 단백질의 완충물질의 변화, 전해질 해리의 감소와 암 모니아 생성 등에 의한 것으로 보고되고 있다(11).

소고기의 육색과 지방색은 등급 및 소비자들의 구매에도 중요하고 영향을 준다(12). 저장 방법에 따른 소고기의 저장 중 색변화는 Table 3 과 같이 저장 초기 명도를 나타내는 $\mathrm{L}$ 값은 39.77에서 $\mathrm{EPS}$ 는 저장 3 일에 40.37로 차이를 나타내 지 않았으나. TCS- 1 와 TCS- 2 의 L 값은 저장 9 일 후 각각 48.57와 43.42로 저장 기간 동안 유의적으로 증가하는 것으 로 측정되었다 $(\mathrm{p}<0.05) . \mathrm{a}$ 값은 저장초기 32.60 에서 모든 처리구에서 저장 기간이 경과될수록 감소하는 경향을 보였 다. 대조구는 저장 3 일째에 14.66로 나타나 소고기의 붉은 색이 크게 감소한 것으로 나타났으며, 저장 7일 TCS-2는 20.34 , 저장 9 일 TCS-1은 18.09 로 측정되어 소고기의 붉은 색이 가장 크게 변화된 것으로 나타났다. 이는 Brewer와 Habers(13)가 분쇄 돈육을 냉동 저장하였을 경우 시간이 경과됨에 따라 적색도는 감소하였다고 한 보고와 일치하였

Table 2. Change in $\mathrm{pH}$ of beef during storage

\begin{tabular}{ccccccccc}
\hline \multirow{2}{*}{ Treatment $^{1)}$} & \multicolumn{7}{c}{ Storage period (day) } \\
\cline { 2 - 9 } & 0 & 1 & 2 & 3 & 4 & 7 & 9 & 11 \\
\hline Control & $\left.5.25 \pm 0.02^{\mathrm{c} 2 \mathrm{~A} 3}\right)$ & $5.51 \pm 0.04^{\mathrm{bA}}$ & $5.51 \pm 0.03^{\mathrm{bA}}$ & $5.71 \pm 0.12^{\mathrm{aA}}$ & - & - & - & - \\
TCS-1 & $5.25 \pm 0.02^{\mathrm{cA}}$ & - & $5.40 \pm 0.02^{\mathrm{bA}}$ & - & $5.34 \pm 0.04^{\mathrm{bB}}$ & $5.51 \pm 0.03^{\mathrm{aB}}$ & $5.53 \pm 0.04^{\mathrm{a}}$ & $5.52 \pm 0.04^{\mathrm{a}}$ \\
TCS-2 & $5.25 \pm 0.02^{\mathrm{cA}}$ & - & $5.41 \pm 0.06^{\mathrm{bA}}$ & - & $5.42 \pm 0.06^{\mathrm{bA}}$ & $5.70 \pm 0.07^{\mathrm{aA}}$ & $5.71 \pm 0.07^{\mathrm{a}}$ & - \\
\hline
\end{tabular}

${ }^{1)}$ Control, beef in expandable polystyrene box; TCS-1, beef in box with thermoelectric cooling system and plasma generation apparatus; TCS-2, beef in box with thermoelectric cooling system.

2)ab Means in the same row with different superscripts are significantly different $(\mathrm{p}<0.05)$.

${ }^{3) A-B}$ Means in the same column with different superscripts are significantly different $(p<0.05)$.

Table 3. Change in color value of beef during storage

\begin{tabular}{|c|c|c|c|c|c|c|c|c|c|}
\hline & \multirow{2}{*}{ Treatment ${ }^{1)}$} & \multicolumn{8}{|c|}{ Storage period (day) } \\
\hline & & 0 & 1 & 2 & 3 & 4 & 7 & 9 & 11 \\
\hline \multirow{3}{*}{$\mathrm{L}$} & Control & $39.77 \pm 2.82^{22) A 3)}$ & $40.43 \pm 4.99^{\mathrm{aA}}$ & $43.37 \pm 6.28^{\mathrm{aA}}$ & $40.37 \pm 4.68^{\mathrm{aA}}$ & - & - & - & - \\
\hline & TCS-1 & $39.77 \pm 2.82^{\mathrm{cA}}$ & - & $42.97 \pm 4.60^{\mathrm{bcA}}$ & - & $41.74 \pm 4.09^{\mathrm{bcA}}$ & $41.60 \pm 3.68^{\mathrm{bcA}}$ & $48.57 \pm 6.63^{\mathrm{aA}}$ & $44.90 \pm 5.90^{\mathrm{abA}}$ \\
\hline & TCS-2 & $39.77 \pm 2.82^{\mathrm{bA}}$ & - & $40.24 \pm 4.75^{\mathrm{bA}}$ & - & $45.01 \pm 5.86^{\mathrm{aA}}$ & $43.36 \pm 3.17^{\mathrm{abA}}$ & $43.42 \pm 4.57^{\mathrm{abA}}$ & - \\
\hline \multirow{3}{*}{$\mathrm{a}$} & Control & $32.60 \pm 2.09^{\mathrm{aA}}$ & $24.64 \pm 4.81^{\mathrm{bA}}$ & $24.16 \pm 4.99^{\mathrm{bB3})}$ & $14.66 \pm 2.33^{\mathrm{cA}}$ & - & - & - & - \\
\hline & TCS-1 & $32.60 \pm 2.09^{\mathrm{aA}}$ & - & $27.89 \pm 2.87^{\mathrm{bA}}$ & - & $26.88 \pm 0.60^{\mathrm{bA}}$ & $23.22 \pm 2.32^{\mathrm{cA}}$ & $20.34 \pm 3.16^{\mathrm{dA}}$ & $18.09 \pm 2.00^{\mathrm{eA}}$ \\
\hline & TCS-2 & $32.60 \pm 2.09^{\mathrm{aA}}$ & - & $29.17 \pm 2.76^{\mathrm{bA}}$ & - & $25.40 \pm 3.73^{\mathrm{cA}}$ & $18.63 \pm 2.65^{\mathrm{dB}}$ & $18.32 \pm 1.75^{\mathrm{dA}}$ & - \\
\hline \multirow{3}{*}{$\mathrm{b}$} & Control & $15.31 \pm 0.93^{\mathrm{aA}}$ & $14.07 \pm 1.84^{\mathrm{aA}}$ & $14.03 \pm 1.38^{\mathrm{aA}}$ & $10.93 \pm 1.67^{\mathrm{bA}}$ & - & - & - & - \\
\hline & TCS-1 & $15.31 \pm 0.93^{\mathrm{aA}}$ & - & $14.69 \pm 1.13^{\mathrm{aA}}$ & - & $14.33 \pm 0.98^{\mathrm{abA}}$ & $12.93 \pm 1.09^{\mathrm{cdA}}$ & $13.53 \pm 1.13^{\mathrm{bcA}}$ & $12.34 \pm 1.19^{\mathrm{dA}}$ \\
\hline & TCS-2 & $15.31 \pm 0.93^{\mathrm{aA}}$ & - & $15.08 \pm 0.99^{\mathrm{aA}}$ & - & $14.94 \pm 1.07^{\mathrm{aA}}$ & $12.40 \pm 1.08^{\mathrm{bA}}$ & $12.26 \pm 0.84^{\mathrm{bB}}$ & - \\
\hline
\end{tabular}

${ }^{1)}$ Control, beef in expandable polystyrene box; TCS-1, beef in box with thermoelectric cooling system and plasma generation apparatus; TCS-2, beef in box with thermoelectric cooling system.

2)ace Means in the same row with different superscripts are significantly different $(\mathrm{p}<0.05)$.

${ }^{3) A-B}$ Means in the same column with different superscripts are significantly different $(p<0.05)$. 
다. b 값 또한 저장 초기 15.31 에서 대조구는 저장 3 일 10.93 로 감소하였고, 저장 9 일째 TCS-1은 $13.53, \mathrm{TCS}-2$ 는 12.26 로 유의적으로 감소하는 경향을 보였다 $(\mathrm{p}<0.05)$.

\section{VBN 및 TBA}

소고기의 저장 중 $\mathrm{VBN}$ 변화는 초기 $6.98 \mathrm{mg} \%$ 로 측정되 었고, 저장기간이 경과될수록 모든 처리구에서 유의적으로 점차 증가하는 경향을 보였다(Table 4). 대조구는 저장 3 일 째 $13.61 \mathrm{mg} \%$ 로 유의적인 증가가 나타났으며 외관과 냄새 에서 관능적으로 부패된 것으로 보였다( $\mathrm{p}<0.05)$. Byun 등 (14)은 VBN 함량이 $18 \mathrm{mg} \%$ 이상에서 부패취와 외관에서 관능적 부패가 인정된다고 보고한 바 있으나, 본 연구에서 는 저장 3 일 이후 부패취 및 관능적 부패가 인정되어 분석이 불가능하였다. 저장 7일 TCS-1은 $7.72 \mathrm{mg} \%, \mathrm{TCS}-2$ 는 9.20 $\mathrm{mg} \%$ 로 측정되었고, 저장 9일 TCS- 1 은, $9.03 \mathrm{mg} \%$, TCS-2는 $11.45 \mathrm{mg} \%$ 로 TCS-2 처리구의 VBN 함량이 TCS- 1 처리구 보다 크게 증가한 것으로 측정되었다. $\mathrm{VBN}$ 의 $\mathrm{NVRQS(15)}$ 의 기준은 $20 \mathrm{mg} \%$ 로 저장기간 동안 모든 처리구는 부패기 준에 부합하지는 않았으나 식용으로 사용하기에는 적합하 지 않은 것으로 판단되었다.

저장 중 TBA 변화는 저장 초기 $0.14 \mathrm{mgMA} / \mathrm{kg}$ 에서 EPS 는 저장 1 일에 $0.51,3$ 일에 $1.68 \mathrm{mgMA} / \mathrm{kg}$ 으로 유의적으로 급격히 증가하는 경향을 보였고( $\mathrm{p}<0.05)$, 나머지 처리구는 저장 4 일까지 $0.40 \mathrm{mgMA} / \mathrm{kg}$ 이하의 $\mathrm{TBA}$ 를 나타내었다.
하지만 저장 9일에 TCS-1은 0.53, TCS-2는 $1.12 \mathrm{mgMA} / \mathrm{kg}$ 으로 TCS-2 TBA 변화가 큰 것으로 측정되었다. Brewer와 Harbers 등(16)에 의하면 TBA 값은 저장기간에 따라 지방 이 산화되어 1 차 생성물질인 hydroperoxide가 2 차 산화생성 물로 분해되어 유기산, 알데하이드, 케톤, 알코올, 카보닐기 및 중합체 등이 계속 생성되고 또한 미생물 대사와 지방분 해 효소에 의해 생성되는 분해물질에 의한 것이라고 보고하 였으며 본 실험에서도 저장기간이 경과함에 따라 TBA 값 이 증가하는 것으로 측정되었다.

\section{육즙손실}

저장 중 소고기의 육즙손실을 측정한 결과는 Table 6 과 같다. 저장 초기 $0.78 \%$ 에서 저장 3 일째 $3.45 \%$ 로 가장 큰 육즙손실을 나타내었고, 나머지 처리구는 $1.00-1.14 \%$ 로 측 정되었다. 저장 3 일째에 대조구는 $3.45 \%$ 의 유의적으로 큰 육즙손실을 보였고, 저장 4 일째 TCS-1, TCS-2 모두 $1.02-1.16 \%$ 의 손실을 나타내었다. 저장 9일째 TCS- 1 은 $1.19 \%, \mathrm{TCS}-2$ 는 $1.68 \%$ 로 측정되었으나 유의적인 차이를 나타내지 않는 것으로 측정되었다. 이러한 결과는 지육을 $4^{\circ} \mathrm{C}$ 에서 7 일간 저장 중에 발생한 육즙 손실량은 평균 $4.35 \%$ 이라는 Kim 등(17)의 보고보다는 낮았으며 이는 본 연구에 서는 더 낮은 온도에서 저장을 하였기 때문으로 판단된다. Van Laack 등(18)은 유리 육즙량이 5\% 이상이면 정상육에 속하지 않는다고 하였으나 본 연구에서는 $5 \%$ 이하로 측정

Table 4. Change in VBN of beef during storage

(unit: $\mathrm{mg} \%$ )

\begin{tabular}{ccccccccc}
\hline \multirow{2}{*}{ Treatment $^{1)}$} & \multicolumn{7}{c}{ Storage period (day) } \\
\cline { 2 - 9 } & 0 & 1 & 2 & 3 & 4 & 7 & 9 & 11 \\
\hline Control & $6.98 \pm 0.27^{\mathrm{b} 2) \mathrm{A} 3)}$ & $7.25 \pm 0.34^{\mathrm{bA}}$ & $8.11 \pm 0.55^{\mathrm{bA}}$ & $13.61 \pm 0.88^{\mathrm{aA}}$ & - & - & - & - \\
TCS-1 & $6.98 \pm 0.27^{\mathrm{dA}}$ & - & $7.44 \pm 0.15^{\mathrm{cA}}$ & - & $7.36 \pm 0.18^{\mathrm{cAA}}$ & $7.72 \pm 0.16^{\mathrm{cB}}$ & $9.03 \pm 0.33^{\mathrm{bB}}$ & $9.77 \pm 0.28^{\mathrm{aA}}$ \\
TCS-2 & $6.98 \pm 0.27^{\mathrm{cA}}$ & - & $7.37 \pm 0.16^{\mathrm{cA}}$ & - & $7.35 \pm 0.19^{\mathrm{cA}}$ & $9.20 \pm 0.72^{\mathrm{bA}}$ & $11.45 \pm 0.81^{\text {aA }}$ & - \\
\hline
\end{tabular}

${ }^{1)}$ Control, beef in expandable polystyrene box; TCS-1, beef in box with thermoelectric cooling system and plasma generation apparatus; TCS-2, beef in box with thermoelectric cooling system.

${ }^{2) a-d}$ Means in the same row with different superscripts are significantly different $(\mathrm{p}<0.05)$

${ }^{3) A-B}$ Means in the same column with different superscripts are significantly different $(\mathrm{p}<0.05)$.

Table 5. Change in TBA of beef during storage

(unit: $\mathrm{mgMA} / \mathrm{kg}$ )

\begin{tabular}{ccccccccc}
\hline \multirow{2}{*}{ Treatment $^{1)}$} & \multicolumn{7}{c}{ Storage period (day) } \\
\cline { 2 - 9 } & 0 & 1 & 2 & 3 & 4 & 7 & 9 & 11 \\
\hline Control & $0.14 \pm 0.02^{\mathrm{d} 2) \mathrm{A} 3)}$ & $0.51 \pm 0.01^{\mathrm{CA}}$ & $0.62 \pm 0.03^{\mathrm{bA}}$ & $1.68 \pm 0.11^{\mathrm{aA}}$ & - & - & - & - \\
TCS-1 & $0.14 \pm 0.02^{\mathrm{CA}}$ & - & $0.25 \pm 0.01^{\mathrm{BB}}$ & - & $0.34 \pm 0.12^{\mathrm{bA}}$ & $0.52 \pm 0.01^{\mathrm{aB}}$ & $0.53 \pm 0.03^{\mathrm{aB}}$ & $0.57 \pm 0.03^{\mathrm{aA}}$ \\
TCS-2 & $0.14 \pm 0.02^{\mathrm{dA}}$ & - & $0.23 \pm 0.03^{\mathrm{dB}}$ & - & $0.40 \pm 0.05^{\mathrm{cA}}$ & $0.91 \pm 0.09^{\mathrm{bA}}$ & $1.12 \pm 0.20^{\mathrm{aA}}$ & - \\
\hline
\end{tabular}

${ }^{1)}$ Control, beef in expandable polystyrene box; TCS-1, beef in box with thermoelectric cooling system and plasma generation apparatus; TCS-2, beef in box with thermoelectric cooling system.

${ }^{2) a-c}$ Means in the same row with different superscripts are significantly different $(\mathrm{p}<0.05)$.

${ }^{3) A-B}$ Means in the same column with different superscripts are significantly different $(p<0.05)$. 
Table 6. Change in drip loss of beef during storage

(unit: \%)

\begin{tabular}{ccccccccc}
\hline \multirow{2}{*}{ Treatment } & \multicolumn{7}{c}{ Storage period (day) } \\
\cline { 2 - 8 } & 0 & 1 & 2 & 3 & 4 & 7 & 9 & 11 \\
\hline Control & $0.78 \pm 0.88^{\mathrm{b} 2) \mathrm{A} 3)}$ & $1.33 \pm 0.22^{\mathrm{abA}}$ & $1.45 \pm 0.20^{\mathrm{abA}}$ & $3.45 \pm 1.95^{\mathrm{aA}}$ & - & - & - & - \\
TCS-1 & $0.78 \pm 0.88^{\mathrm{aA}}$ & - & $1.00 \pm 0.48^{\mathrm{aA}}$ & - & $1.02 \pm 0.14^{\mathrm{aA}}$ & $1.19 \pm 0.48^{\mathrm{aA}}$ & $1.19 \pm 0.36^{\mathrm{aA}}$ & $1.52 \pm 0.76^{\mathrm{aA}}$ \\
TCS-2 & $0.78 \pm 0.88^{\mathrm{aA}}$ & - & $1.14 \pm 0.13^{\mathrm{aA}}$ & - & $1.16 \pm 0.11^{\mathrm{aA}}$ & $1.34 \pm 0.31^{\mathrm{aA}}$ & $1.68 \pm 0.54^{\mathrm{aA}}$ & - \\
\hline
\end{tabular}

${ }^{1)}$ Control, beef in expandable polystyrene box; TCS-1, beef in box with thermoelectric cooling system and plasma generation apparatus; TCS-2, beef in box with thermoelectric cooling system.

${ }^{2) a b}$ Means in the same row with different superscripts are significantly different $(\mathrm{p}<0.05)$

${ }^{3) A-B}$ Means in the same column with different superscripts are significantly different $(p<0.05)$

Table 7. Change in total microbial count of beef during storage

(unit: $\log \mathrm{CFU} / \mathrm{mL}$ )

\begin{tabular}{|c|c|c|c|c|c|c|c|c|}
\hline \multirow{2}{*}{ Treatment $^{1)}$} & \multicolumn{8}{|c|}{ Storage period (day) } \\
\hline & 0 & 1 & 2 & 3 & 4 & 7 & 9 & 11 \\
\hline Control & $1.55 \pm 0.04^{(2) A 3)}$ & $3.23 \pm 1.10^{\mathrm{cA}}$ & $4.63 \pm 013^{\mathrm{bA}}$ & $8.45 \pm 0.38^{\mathrm{aA}}$ & - & - & - & - \\
\hline TCS-1 & $1.55 \pm 0.04^{\mathrm{cA}}$ & - & $1.79 \pm 0.47^{\mathrm{cB}}$ & - & $1.85 \pm 0.20^{\mathrm{cA}}$ & $4.62 \pm 0.58^{\mathrm{bB}}$ & $5.92 \pm 0.79^{\mathrm{aA}}$ & $6.38 \pm 0.53^{\mathrm{aA}}$ \\
\hline TCS-2 & $1.55 \pm 0.04^{\mathrm{cA}}$ & - & $1.99 \pm 0.26^{\mathrm{cB}}$ & - & $3.67 \pm 1.17^{\mathrm{bA}}$ & $7.09 \pm 0.89^{\mathrm{aA}}$ & $7.71 \pm 0.81^{\mathrm{aA}}$ & - \\
\hline
\end{tabular}

${ }^{1)}$ Control, beef in expandable polystyrene box; TCS-1, beef in box with thermoelectric cooling system and plasma generation apparatus; TCS-2, beef in box with thermoelectric cooling system.

2)a-c Means in the same row with different superscripts are significantly different $(\mathrm{p}<0.05)$

${ }^{3) A-B}$ Means in the same column with different superscripts are significantly different $(\mathrm{p}<0.05)$

Table 8. Changes in sensory properties of fresh beef during storage

\begin{tabular}{|c|c|c|c|c|c|c|c|c|c|}
\hline \multirow{2}{*}{ Items } & \multirow{2}{*}{ Treatment ${ }^{1)}$} & \multicolumn{8}{|c|}{ Storage period (day) } \\
\hline & & 0 & 1 & 2 & 3 & 4 & 7 & 9 & 11 \\
\hline \multirow{3}{*}{ Appearance } & Control & $9.0 \pm 0.0^{22) \mathrm{A} 3)}$ & $8.1 \pm 0.7^{\mathrm{bA}}$ & $6.4 \pm 1.0^{\mathrm{cB}}$ & $1.6 \pm 0.7^{\mathrm{dA}}$ & - & - & - & - \\
\hline & TCS-1 & $9.0 \pm 0.0^{\mathrm{aA}}$ & - & $7.9 \pm 0.7^{\mathrm{bA}}$ & - & $7.7 \pm 1.1^{\mathrm{bA}}$ & $6.8 \pm 1.3^{\mathrm{cA}}$ & $3.2 \pm 0.8^{\mathrm{dA}}$ & $2.9 \pm 1.3^{\mathrm{dA}}$ \\
\hline & TCS-2 & $9.0 \pm 0.0^{\mathrm{aA}}$ & - & $7.9 \pm 1.1^{\mathrm{bA}}$ & - & $7.6 \pm 0.8^{\mathrm{bA}}$ & $4.0 \pm 1.8^{\mathrm{cB}}$ & $1.5 \pm 0.5^{\mathrm{dB}}$ & - \\
\hline \multirow{3}{*}{ Color } & Control & $9.0 \pm 0.0^{\mathrm{aA}}$ & $8.1 \pm 0.7^{b \mathrm{~A}}$ & $6.1 \pm 0.9^{c}$ & $1.5 \pm 0.7^{\mathrm{dA}}$ & - & - & - & - \\
\hline & TCS-1 & $9.0 \pm 0.0^{\mathrm{aA}}$ & - & $8.0 \pm 0.7^{\mathrm{b}}$ & - & $7.7 \pm 1.0^{\mathrm{bcA}}$ & $7.0 \pm 1.2^{\mathrm{cA}}$ & $3.0 \pm 0.7^{\mathrm{dA}}$ & $2.8 \pm 1.4^{\mathrm{dA}}$ \\
\hline & TCS-2 & $9.0 \pm 0.0^{\mathrm{aA}}$ & - & $7.9 \pm 1.1^{b}$ & - & $7.9 \pm 0.7^{\mathrm{bA}}$ & $3.4 \pm 1.8^{\mathrm{cA}}$ & $1.6 \pm 1.0^{\mathrm{dB}}$ & - \\
\hline \multirow{3}{*}{ Off-flavor } & Control & $9.0 \pm 0.0^{\mathrm{aA}}$ & $8.1 \pm 1.0^{\mathrm{bA}}$ & $6.3 \pm 1.3^{\mathrm{cB}}$ & $1.2 \pm 0.4^{\mathrm{dA}}$ & - & - & - & - \\
\hline & TCS-1 & $9.0 \pm 0.0^{\mathrm{aA}}$ & - & $8.0 \pm 0.7^{\mathrm{bA}}$ & - & $8.3 \pm 0.8^{\mathrm{abA}}$ & $6.5 \pm 1.4^{\mathrm{cA}}$ & $2.6 \pm 0.7^{\mathrm{dA}}$ & $2.2 \pm 1.0^{\mathrm{dA}}$ \\
\hline & TCS-2 & $9.0 \pm 0.0^{\mathrm{aA}}$ & - & $8.0 \pm 1.2^{\mathrm{abA}}$ & - & $7.5 \pm 1.3^{\mathrm{bB}}$ & $2.9 \pm 1.5^{\mathrm{cB}}$ & $1.3 \pm 0.7^{\mathrm{dB}}$ & - \\
\hline \multirow{3}{*}{ Juiciness } & Control & $9.0 \pm 0.0^{\mathrm{aA}}$ & $8.2 \pm 1.0^{\mathrm{bA}}$ & $7.1 \pm 0.9^{\mathrm{cB}}$ & $1.7 \pm 0.8^{\mathrm{dA}}$ & - & - & - & - \\
\hline & TCS-1 & $9.0 \pm 0.0^{\mathrm{aA}}$ & - & $7.9 \pm 0.3^{\mathrm{abA}}$ & - & $7.8 \pm 0.9^{\mathrm{abA}}$ & $7.0 \pm 1.6^{\mathrm{bA}}$ & $4.3 \pm 1.8^{\mathrm{cA}}$ & $3.2 \pm 1.6^{\mathrm{cA}}$ \\
\hline & TCS-2 & $9.0 \pm 0.0^{\mathrm{aA}}$ & - & $8.0 \pm 0.9^{\mathrm{bA}}$ & - & $7.6 \pm 1.1^{\mathrm{bA}}$ & $4.1 \pm 1.7^{\mathrm{cB}}$ & $2.8 \pm 1.7^{\mathrm{dB}}$ & - \\
\hline \multirow{3}{*}{$\begin{array}{c}\text { Overall } \\
\text { acceptability }\end{array}$} & Control & $9.0 \pm 0.0^{\mathrm{aA}}$ & $8.0 \pm 0.8^{\mathrm{bA}}$ & $6.3 \pm 0.8^{\mathrm{cB}}$ & $1.3 \pm 0.5^{\mathrm{dA}}$ & - & - & - & - \\
\hline & TCS-1 & $9.0 \pm 0.0^{\mathrm{aA}}$ & - & $7.8 \pm 0.4^{\mathrm{bA}}$ & - & $7.6 \pm 1.2^{\mathrm{bA}}$ & $6.5 \pm 1.4^{\mathrm{cA}}$ & $3.0 \pm 0.8^{\mathrm{dA}}$ & $2.3 \pm 1.3^{\mathrm{dA}}$ \\
\hline & TCS-2 & $9.0 \pm 0.0^{\mathrm{aA}}$ & - & $8.1 \pm 1.0^{\mathrm{bA}}$ & - & $7.8 \pm 0.9^{\mathrm{bA}}$ & $2.8 \pm 1.6^{\mathrm{CB}}$ & $1.7 \pm 0.7^{\mathrm{dB}}$ & - \\
\hline
\end{tabular}

${ }^{11}$ Control, Beef in expandable polystyrene box; TCS-1, Beef in box with thermoelectric cooling system and plasma generation apparatus; TCS-2, Beef in box with thermoelectric cooling system.

2)ad- Means in the same row with different superscripts are significantly different $(p<0.05)$

${ }^{3) A-B}$ Means in the same column with different superscripts are significantly different $(p<0.05)$. 
되어, TCS-1 과 TCS-2 모두 육즙손실이 낮은 것으로 판단된다.

\section{미생물 변화}

저장 유통 중 쇠고기의 품질 및 위생 상태에 가장 큰 영향을 미치는 것이 육류 표면에 생육하는 미생물 수이며 미생물이 $6 \log \mathrm{CFU} / \mathrm{g}$ 또는 $7 \log \mathrm{CFU} / \mathrm{g}$ 수준에 도달하면 부패가 시작되고 8-9 $\log \mathrm{CFU} / \mathrm{g}$ 일 때 관능적인 성질이 저하 되어 부패취가 심하게 난다고 보고되었다(19). 본 실험에 사용한 소고기의 초기 총균수는 $1.55 \log \mathrm{CFU} / \mathrm{mL}$ 로 측정되 었고 저장기간이 지남에 따라 모든 처리구의 미생물 증식이 유의적으로 증가하였다 $(\mathrm{p}<0.05)$. 대조구는 저장 3 일에 8.45 $\log \mathrm{CFU} / \mathrm{mL}$ 로 증식하여 부패가 발생하였음을 알 수 있었 고, 저장 4일 TCS-1은 $1.85 \log \mathrm{CFU} / \mathrm{mL}$ 로 유의적인 변화는 없었으나 TCS-2는 $3.67 \log \mathrm{CFU} / \mathrm{mL}$ 로 미생물이 증식한 것으로 측정되었다. 저장 9일 TCS-1은 $5.92 \log \mathrm{CFU} / \mathrm{mL}$, TCS-2는 $7.71 \log \mathrm{CFU} / \mathrm{mL}$ 로 측정되어 TCS-2는 부패가 시 작되는 수준으로 측정되어 플라즈마 처리가 초기 미생물 증식 억제에 효과가 있는 것으로 판단되었다.

\section{기호도 조사}

처리방법에 따른 저장 기간 동안 소고기의 기호도 조사 는 Table 8 에 나타낸 것과 같이 대조구의 경우 저장 2 일까지 모든 항목에서 6.1 이상의 평가를 받았으나 저장 3 일 모든 항목에서 1.7 이하의 평가를 받아 상품성이 상실된 것을 알 수 있었다(19). Rho 등(20)은 육류의 근내 지방 부분의 색을 비교해 보았을 때 노랗지 않은 것을 소비자들이 선호 하는데 이는 지방의 산패에 관련이 있다고 하였으며, 대조 구의 경우 TBA가가 저장기간이 지남에 따라 유의적으로 점차 증가하는 것과 같이 색의 관능 평가도 저장기간에 따라 유의적으로 낮아지는 것을 확인할 수 있었다. 소고기 색 항목은 저장 4 일째에 TCS-1과 TCS-2는 각각 7.7과 7.9점 의 평가를 받아 유의적인 변화 없이 유지되었으나 저장 7일째 TCS-2가 3.4점으로 평가를 받아 유의적 차이를 나타 내었다(p<0.05). TCS-1은 저장 7일 모든 항목에서 6.5점 이상의 평가를 받았으나, TCS-2는 4.1점 이하의 평가를 받 아 상품성이 상실된 것으로 판단되었다.

본 연구에서 농산물 유통 중 안정성을 유지하기 위한 저온 이동식 컨테이너를 제작하여 기존의 유통 방법인 EPS 박스와 비교한 결과, 개발된 컨테이너인 TCS-1과 TCS-2에 저장된 소고기의 품질이 더 잘 유지됨을 확인할 수 있었으 며 특히, 플라즈마 처리를 한 TCS-1에 저장된 소고기가 모든 분석항목에서 TCS-1에 비해 신선도 유지에 효과적인 것을 알 수 있었다.

\section{요 약}

본 연구에서는 열전소자와 플라즈마 장치를 삽입하여
제작된 컨테이너와 기존의 사용되고 있는 스티로폼(EPS) 박스에 소고기를 저장하면서 저장 중 품질특성을 조사하였 다. 온도변화 측정 결과 저장기간 동안 TCS- 1 컨테이너가 $2{ }^{\circ} \mathrm{C}$ 이하로 온도유지가 잘 되는 것으로 측정되었다. EPS 박스는 저장 3 일 이후 소고기가 부패되어 더 이상 실험이 불가능 하였다. 소고기의 신선도를 나타내는 휘발성염기질 소(VBN)과 지방산패도(TBA)값의 측정 결과, 저장 7일째 TCS-1의 VBN은 $7.72 \mathrm{mg} \%$, TBA는 $0.52 \mathrm{mgMA} / \mathrm{kg}$, TCS-2 의 $\mathrm{VBN}$ 값은 $9.20 \mathrm{mg} \%, \mathrm{TBA}$ 는 $0.91 \mathrm{mgMA} / \mathrm{kg}$ 로 측정되어 TCS-1이 TCS-2 보다 유의적으로 적은 증가율을 나타내어 소고기의 신선도를 더 잘 유지하는 것으로 판단되었다. 미 생물 변화는 저장 7일 TCS-1은 $4.62 \log \mathrm{CFU} / \mathrm{g}$, TCS-2는 $7.09 \log \mathrm{CFU} / \mathrm{g}$ 으로 측정되어 TCS-1이 유의적으로 미생물 증식 억제에 효과적인 것으로 나타났다. 기호도 조사 또한 저장 7일째 TEU-1은 모든 항목에서 6.5점 이상의 평가를 받았으나 TCS-2는 4.1 이하의 평가를 받아 소고기의 상품 성이 상실된 것으로 판단되었다. 모든 분석항목에서 TCS-1 이 TCS-2보다 소고기 신선도 유지에 효과적인 것으로 판단 되었다.

\section{References}

1. Kim G, Lee KJ, Choi KH, Choi DS, Son JR, Kang S, Chang YC (2004) Odor analysis for beef freshness estimation with electronic nose. J Biosystems Eng, 29, 317-322

2. Selcuk M, Oksuz L, Basaran P (2008) Decontamination of grains and legumes infected with Aspergillus spp. and Penicillum spp. by cold plasma treatment. Bioresour Technol, 99, 5104-5109

3. Perni S, Liu DW, Shama G, Kong MG (2008) Cold atmospheric plasma decontamination of the pericarps of fruit. J Food Prot, 71, 302-308

4. Laroussi M, Leipold F (2004) Evaluation of the roles of reactive species, heat, and UV radiation in the inactivation of bacterial cells by air plasmas at atmospheric pressure. Int J Mass Spectrom, 233, 81-86

5. Ngadi M, Smith JP, Cayouette B (2003) Kinetics of ultraviolet light inactivation of Escherichia coli O157:H7 in liquid foods. J Sci Food Agric, 83, 1551-1555

6. Bolshakov AA, Cruden BA, Mogul R, Rao MVVS, Sharma SP, Khare BN, Meyyappan M (2004) Radio-frequency oxygen plasma as a sterilization source. AIAA J, 42, 823-832

7. Ingram M, Roberts TA (1976) The microbiology of the red meat carcass and the slaughterhouse. R Soc Health 
J, 96, 270-276

8. Heo JH, Park YH, Koo JH, Cho MH, Lee JH, Rim SK (1998) Bacteriological study on carcasses and environmental specimens from different stage of slaughter process. Korean J Vet serv, 21, 157-161

9. Heo JH, Son SK, Lee JH, Rim SK, Ku JH, Park YH, Cho MH, Son WG, Kang HJ (1997) Isolation of Listeria monocytogenes from animal carcasses and environmental specimens in slaughter house level. Korean J Vet service, 20, 69-78

10. Zamora MC, Zaritzky NE (1985) Modelling of microbial growth in refrigerated packaged beef. J Food Sci, 50, 1003-1006

11. Park JA, Joo SY, Hwang HJ, Na YS, Kim SJ, Choi JI, Ha JY, Cho MS (2016) Effects of freezing storage temperature on the storage stability of beef. Korean $\mathbf{J}$ Food Sci Technol, 48, 301-305

12. Kang SJ, Moon YH, Park KS, Park HS, Jung IC (2010) Effect of maturity and marbling score on meat quality properties on Korean native fattening Hanwoo. J East Asian Soc Dietary Life, 20, 248-253

13. Brewer MS, Harbers CAZ (1991) Effect of packaging on color and physical characteristics of ground pork in long-term frozen storage. J Food Sci, 56, 363-366

14. Byun MW, Kwon JH, Cho HO, Lee MK, Kim JG (1985) Physicochemical Changes of Gamma-Irradiated Chicken. Korean J Food Sci Technol, 17, 186-191
15. NVRQS (2013) Processing standards and component specification of livestock products. National Veterinary Research and Quarantine Service, Anyang, Korea, p 73

16. Brewer MS, Harbers CAZ (1991) Effect of packaging on physical and sensory characteristics of ground pork in long-term frozen storage. J Food Sci, 56, 627-631

17. Kim CJ, Suck JS, Ko WS, Lee ES (1994) Studies on the cold and frozen storage for the production of high quality meat of Korean native cattle II. Effects of cold and frozen storage on the drip, storage loss and cooking loss in Korean native cattle. Korean J Food Sci An, 14, 155-158

18. Van Laack RLJM, Kauffman RG, Sybesma W, Smulders FJM, Elikelenboom G, Pinheiro JC (1994) Is colour brightness (L-value) a reliable indicator of water holding capacity in porcine muscle?. Meat Sci, 38, 193-201

19. Lee MS, Park SK, Bae DH, Ha SD, Song KB (2004) Effect of soy protein film packaging on the qualities and the microbial growth of beef during storage. Korean $\mathbf{J}$ Food Preserv, 11, 565-568

20. Rho JH, Kim MH, Song HN (2007) A study on the quality characteristics of brand and non-brand Korean beefs. Korean J Food Cookery Sci, 23, 187-194 